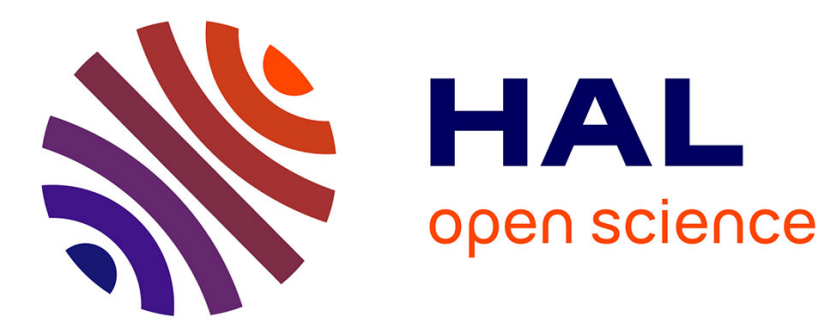

\title{
Expansion of five-year-old mortars attributable to DEF: relevance of the laboratory studies on DEF?
}

\author{
Jean-Emmanuel Aubert, Gilles Escadeillas, Ali-Nordine Leklou
}

\section{To cite this version:}

Jean-Emmanuel Aubert, Gilles Escadeillas, Ali-Nordine Leklou. Expansion of five-year-old mortars attributable to DEF: relevance of the laboratory studies on DEF?. Construction and Building Materials, 2009, 23, pp.3583-3585. 10.1016/j.conbuildmat.2009.08.015 . hal-01006828

\section{HAL Id: hal-01006828 \\ https://hal.science/hal-01006828}

Submitted on 16 Oct 2018

HAL is a multi-disciplinary open access archive for the deposit and dissemination of scientific research documents, whether they are published or not. The documents may come from teaching and research institutions in France or abroad, or from public or private research centers.
L'archive ouverte pluridisciplinaire HAL, est destinée au dépôt et à la diffusion de documents scientifiques de niveau recherche, publiés ou non, émanant des établissements d'enseignement et de recherche français ou étrangers, des laboratoires publics ou privés. 


\title{
Expansion of five-year-old mortars attributable to DEF: Relevance of the laboratory studies on DEF?
}

\author{
Jean-Emmanuel Aubert* , Gilles Escadeillas, Nordine Leklou \\ Université de Toulouse, UPS, INSA, LMDC (Laboratoire Matériaux et Durabilité des Constructions), 135, Avenue de Rangueil, F-31 077 Toulouse, France
}

\begin{abstract}
This paper aims to open a discussion on the relevance of the laboratory studies on heat-induced internal sulphate attack. The results presented here show that specimens of mortars conserved in frequently renewed deionised water expand after 3 years and a half. The same specimens conserved in water that is not renewed still do not expand after more than 5 years of conservation. So, it seems that the appearance of the phenomenon is linked to the experimental conditions of the test. Moreover, the period before the beginning of the expansion is very long. These results raise two important questions: may the laboratory studies be used for the prediction of the field DEF behaviour and, if so, what minimal duration should formulation qualification tests have to ensure the durability of the constructions faced with this pathology?
\end{abstract}

\section{Introduction}

In more than 10 years of research, numerous laboratory experiments have been carried out to study heat-induced internal sulphate attack (still commonly referred as Delayed Ettringite Formation or DEF) [1-11]. The main conclusions of this research were summarized at the RILEM workshop on Internal Sulfate Attack and Delayed Ettringite Formation [12]. Most of the time, the tests used in these studies are rather simple: samples of cement paste, mortar or concrete are prepared and cured using a heat treatment representative of the treatments used in the precast industries or, more recently, representative of the heating of a massive piece of concrete. The samples are then conserved in a moist environment or, more frequently, immersed in water without specific precautions. The length of the samples is also measured during the time of the experiment and, if expansion appears, observations using the SEM are made to verify that this expansion is ascribable to the formation of delayed ettringite. The duration of the tests found in the literature varies: from few months to close to 3 years (corresponding to the average duration of a Ph.D. thesis). Lawrence [13] and Yang et al. [14] have presented results obtained on four-year-old cement pastes but this duration of tests is rather anecdotic, the average duration ranging around a year. However, this manner of working has been criticised by many researchers, including Taylor et al. [15] and Diamond [16].

This paper aims to open a discussion on the relevance of the laboratory studies on heat-induced internal sulphate attack by sup-

\footnotetext{
* Corresponding author. Tel.: +33 5615566 97; fax: +33561559949. E-mail address: aubert@insa-toulouse.fr (J.-E. Aubert).
}

porting the reflections with the results obtained on specimens of five-year-old mortars conserved in two conditions: continuously in the same water or in deionised water renewed at each length measurement.

\section{Experimental procedure}

The mortar specimens were prepared using an Ordinary Portland Cement (CEM I $52.5 \mathrm{R}$ type) commonly employed in the precast industry $\left(64.3 \% \mathrm{CaO}, 19.2 \% \mathrm{SiO}_{2}, 5.1 \% \mathrm{Al}_{2} \mathrm{O}_{3}, 3.4 \% \mathrm{SO}_{3}, 2.9 \%\right.$ $\mathrm{MgO}, 2.5 \% \mathrm{Fe}_{2} \mathrm{O}_{3}, 0.7 \% \mathrm{~K}_{2} \mathrm{O}$ and $0.3 \% \mathrm{Na}_{2} \mathrm{O}$ ). The Blaine surface area of the cement was equal to $4200 \mathrm{~cm}^{2} / \mathrm{g}$. The siliceous aggregate was a European sand meeting standard NF EN 196-1. The water/cement ratio was 3 and the sand/cement ratio was 0.5 . Mortar prisms $\left(40 \times 40 \times 160 \mathrm{~mm}^{3}\right)$ were prepared according to the NF EN 196-1 standard. After casting, the mortar specimens were cured using a heat treatment that followed a cycle divided into four phases: a pre-cure at $20^{\circ} \mathrm{C}$ for $1 \mathrm{~h}$, a temperature rise at $20^{\circ} \mathrm{C} / \mathrm{h}$ for $3 \mathrm{~h}$, a temperature plateau at $80^{\circ} \mathrm{C}$ for $10 \mathrm{~h}$ and, finally, a natural return to the ambient temperature of $20^{\circ} \mathrm{C}$ over $11 \mathrm{~h}$. The length of the samples was measured during the time of the experiment and some microscopic observations were carried out using a JEOL 6380 LV equipped with a backscattered electron (BSE) detector and an energy dispersive X-ray analyzer.

The tests were carried out according to the conventional method described in Section 1 of this paper but two conditions of conservation were used. In the first case, the specimens were conserved with other specimens of mortar in large tanks filled with water. In the second case, the specimens were conserved alone in a closed tank filled with deionised water that was 


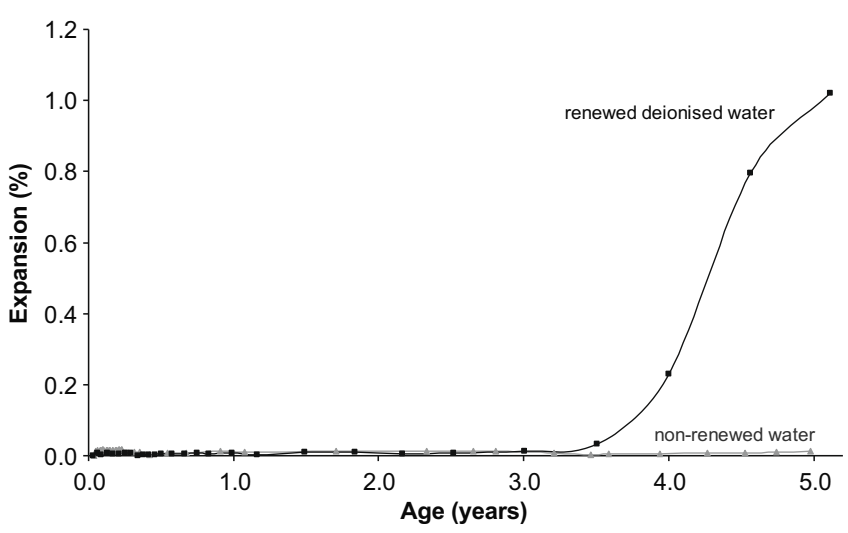

Fig. 1. Length variations of the two mortars.

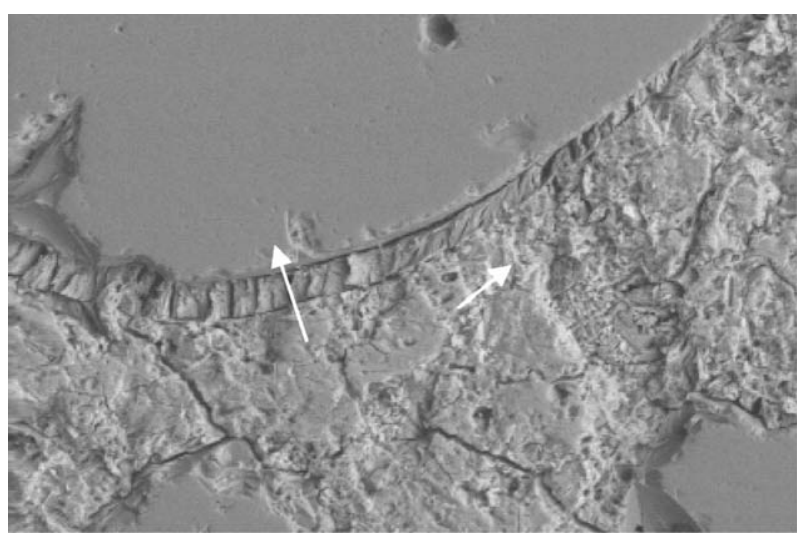

Fig. 2. Microscopic observation of mortar stored in renewed deionised water at 4 years $(B S E, \times 400)$.

renewed at each length measurement, using the same Liquid to Solid ratio of 1.5 .

\section{Results}

Fig. 1 shows the average value of the expansion of three specimens conserved in the two conditions described above.

The specimens conserved in the frequently renewed deionised water began to expand after 3 years and a half. Then, the increase of the expansion was fast and some cracks visible to the naked eye appeared after 4 years for an average expansion near to $0.23 \%$. As shown in Fig. 1, the samples conserved in non-renewed water with other specimens of mortar had not expanded after more than 5 years.

Microscopic examinations were carried out using a Scanning Electron Microscope to verify that the formation of delayed ettringite was the cause of the expansion of the mortar. Fig. 2 shows a microscopic observation of a polished section of a mortar stored in deionised renewed water for 4 years. On this picture, it is possible to clearly recognize a delayed ettringite band at the paste/ aggregate interface and a crack filled with ettringite crossing the paste. The Energy Dispersive X-ray Spectrometer (EDS) analysis of the band around the aggregate confirms the presence of ettringite (Fig. 3).

\section{Discussion and conclusion}

The results presented in this paper are in accordance with the conclusions of Diamond on the relevance of the laboratory studies on delayed ettringite formation to DEF in field concretes [16]. Diamond, who draws his inferences from the works of Famy [3] and Zhang [4], concludes that the immersion of the samples during the laboratory tests strongly influences the appearance of DEF. According to his thinking, the formation of delayed ettringite would be triggered as a consequence of the leaching of alkali hydroxide, accelerated in the case of the immersion of the samples. The results presented in this paper support this hypothesis. In the case of the immersion in renewed deionised water, the gradient of concentration between the pore solution and the conservation solution leads to significant leaching of the ions contained in the pore solution and, in particular, of the alkalis. In the case of conservation in non-renewed water with other samples of mortar, the conservation solution quickly becomes saturated and the ionic exchanges between the mortar and the conservation solution are stopped, which blocks the chain of the phenomena. Also, Diamond concludes that such laboratory studies may not be applicable for predicting DEF susceptibility of field concretes. This conclusion is in part true for field concretes that are not immersed. But what of concrete used for the construction of bridge piers immersed in fresh water? In this case, the concrete is in contact with low-mineralized water that is perpetually renewed. So, it seems that the relevance of the laboratory studies is also linked to the concrete utilization scenarios.

The other question raised by the results of this study concerns the necessary duration of the laboratory tests. If one considers the real requirements of works supervisors in terms of structure lifetimes, these are relatively clear: they ask for easily measurable

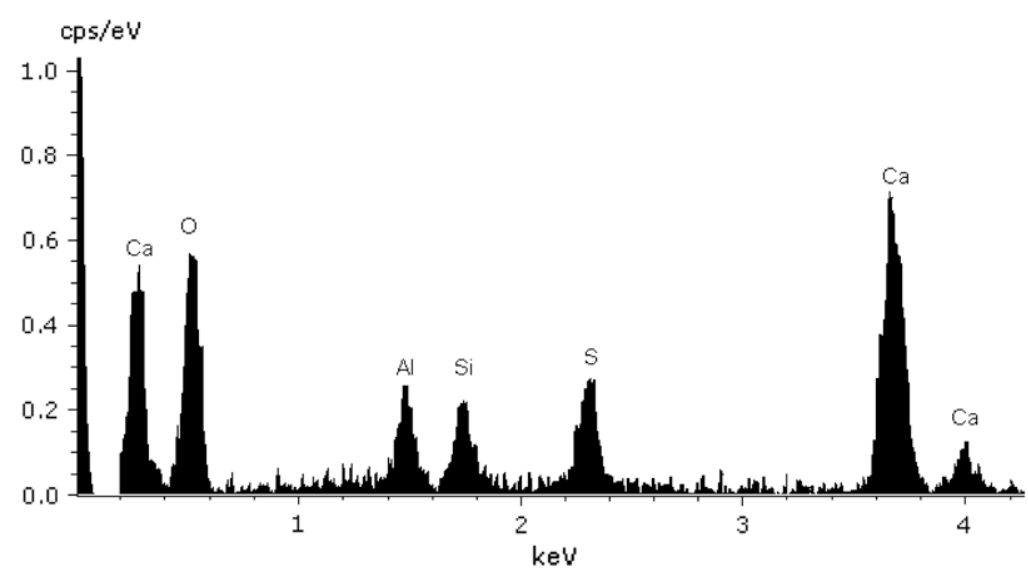

Fig. 3. EDS analysis of the ettringite rim around the paste/aggregate interface of Fig. 2. 
thresholds to be established and obtained in the laboratory after a reasonable time ( 1 year maximum). In the case of heat-induced internal sulphate attack, this does not seem to be possible for the moment. Indeed, the results presented in this paper show that, under some favourable conditions, the expansion could begin after more than 3 years of conservation. In such a case, how is it possible to guarantee the durability of the cement-based materials faced with this pathology for longer and longer construction lifetimes (100 years for the latest European engineering works)?

To reach the objectives mentioned, solutions must be found either by developing accelerated tests as was the case for the alkali silica reaction or by using a model to simulate the evolution of this pathology with time. In both cases, much remains to be done before we are able to provide highly reliable predictions of the behaviour of concrete structures faced with this pathology.

\section{References}

[1] Fu Y. Delayed ettringite formation in portland cement products, Ph.D. Thesis Department of Civil Engineering, University of Ottawa; 1996.

[2] Lewis M. Heat curing and delayed ettringite formation in concretes, Ph.D. Thesis, Imperial College of Science, Technology and Medicine, University of London; 1996.

[3] Famy C. Expansion of heat-cured mortars, Ph.D. Thesis, Imperial College of Sciences, Technology and Medicine, University of London; 1999.

[4] Zhang Z. Delayed ettringite formation in heat cured cementitious systems, Ph.D. Thesis, School of Civil Engineering, Purdue University; 1999.
[5] Divet L. Les réactions sulfatiques internes au béton: contribution à l'étude des mécanismes de la formation différée de l'ettringite, Ph.D. Thesis, Conservatoire National des Arts et Métiers, Laboratoire Central des Ponts et Chaussées; 2001.

[6] Barbarulo R. Comportement des Matériaux Cimentaires: actions des sulfates et de la température, Ph.D. Thesis, Ecole Normale Supérieure de CachanUniversité de Laval; 2002.

[7] Pavoine A. Evaluation du potentiel de réactivité des bétons vis-à-vis de la formation différée de l'ettringite, Ph.D. Thesis, Université Pierre et Marie Curie, Paris VI; 2003.

[8] Petrov N. Combined effect of different factors on concrete expansion due to DEF, Ph.D. Thesis, Université de Sherbrooke; 2003.

[9] Ramlochan T. The effect of pozzolans and slag on the expansion of mortars and concrete cured at elevated temperature, Ph.D. Thesis, University of Toronto; 2003.

[10] Brunetaud X. Etude de l'influence de différents paramètres et de leurs interactions sur la cinétique et l'amplitude de la réaction sulfatique interne au béton, Ph.D. Thesis, Ecole Centrale des Arts et Manufactures; 2005.

[11] Leklou N. Contribution à la connaissance de la réaction sulfatique interne, Ph.D. Thesis, Université de Toulouse; 2008.

[12] Internal sulfate attack and delayed ettringite formation. In: Scrivener K. Skalny, J. editors. Proceedings of the international RILEM TC 186-ISA Workshop. Villars, Switzerland: RILEM Publications; 2002.

[13] Lawrence CD. Mortar expansions due to delayed ettringite formation. Effects of curing period and temperature. Cem Concr Res 1995;25:903-14.

[14] Yang R, Lawrence CD, Sharp JH. Delayed ettringite formation in 4-year old cement pastes. Cem Concr Res 1996;26:1649-59.

[15] Taylor HFW, Famy C, Scrivener KL. Delayed ettringite formation. Cem Concr Res 2001;31:683-93.

[16] Diamond S. The relevance of laboratory studies on delayed ettringite formation to DEF in field concretes. Cem Concr Res 2000;30:1987-91. 